\title{
Analysis of Students' Errors in Solving Problems in Class XII IPA SMA Negeri 5 Soppeng
}

\begin{tabular}{|c|c|}
\hline \multicolumn{2}{|r|}{$\begin{array}{l}\text { Winaldi }{ }^{1} \text {, Gusniwati }{ }^{2} \text {, Andi Aras }{ }^{3} \\
1 \text { Institut Agama Islam Negeri Parepare, INDONESIA } \\
2 \text { Institut Agama Islam Negeri Parepare, INDONESIA } \\
3 \text { Institut Agama Islam Negeri Parepare, INDONESIA }\end{array}$} \\
\hline $\begin{array}{l}\text { ARTICLE'S } \\
\text { INFORMATION }\end{array}$ & ABSTRACT \\
\hline $\begin{array}{l}\text { Article history: } \\
\text { Received: Dec-31-2020 } \\
\text { Reviewed: Jan-27-2021 } \\
\text { Accepted: June-24-2021 }\end{array}$ & $\begin{array}{l}\text { This study aims to describe the types of student errors and the factors that cause } \\
\text { errors in class XII MIPA } 1 \text { SMA Negeri } 5 \text { Soppeng in solving math problems on } \\
\text { statistics. This research is qualitative research using a descriptive research } \\
\text { methodology approach. Data collection was carried out using written tests and } \\
\text { interviews. The subjects in this study were } 31 \text { students of class XII MIPA } 1 \text { SMA } \\
\text { Negeri } 5 \text { Soppeng taken by purposive sampling. The types of student error were } \\
\text { classified according to the Newman procedure. The results of this study indicate that }\end{array}$ \\
\hline $\begin{array}{l}\text { Keywords: } \quad \begin{array}{l}\text { Analysis, } \\
\text { Students' Errors, Solving } \\
\text { Problems }\end{array} \\
\end{array}$ & $\begin{array}{l}\text { errors, comprehension errors, transformation errors, process skills errors, and } \\
\text { encoding errors. The factors that cause student errors are poor network connection } \\
\text { in looking for references to work on questions, unfamiliarity with online learning, } \\
\text { lack of understanding of statistics submitted online, difficulty in the calculation part, } \\
\text { lack of ability or not being used to writing things that are known and things those } \\
\text { who are asked in the questions correctly, lack of practice working on practice } \\
\text { questions related to statistics, do not like maths lessons, are in a hurry to work on } \\
\text { the completion process. The solution to avoid or minimize the occurrence of these } \\
\text { errors is to look for appropriate learning methods, look for references via the internet } \\
\text { or from YouTube videos, students are actively practicing working on problem- } \\
\text { solving types, practicing answering. }\end{array}$ \\
\hline
\end{tabular}

Corresponding address:

Winaldi,

E-mail:winaldi@iainpare.ac.id

\section{INTRODUCTION}

Education is an important part of improving competitiveness by improving the quality of human resources [1]. Education is a conscious and planned effort to create an atmosphere of learning and the learning process so that students actively develop their potential to have spiritual-religious strength, self-control, personality, intelligence, noble character, and skills needed by themselves, society, the nation and the state [2] [3]. Efforts in developing the potential that students have can be done through the learning process of mathematics, namely learning that prioritizes exact, correct and direct knowledge so that it can form discipline in thinking, and train students to think simply, clearly, precisely and quickly.

In general, we know that education is a universal activity in human life, therefore education is very important and a right for everyone. Education is actually a complex series of events, these events are a series of communication activities between humans in order to grow as a whole person. The educational process occurs when the educational components in the educational effort are functionally interconnected in an integrated unit [4]. The educational process is also an activity that is carried out consciously and planned to create a learning atmosphere and learning process [5]. As 
Davies argues, education is essentially learning [6]. Learning is a process of interaction between students and educators and learning resources in a learning environment. Therefore, educators must be able to interact as well as possible with students in learning activities so that the material delivered by educators can be understood and understood by students, and can even attract student participation, so that educators can be said to be successful in carrying out learning.

Efforts to improve the quality of education must be carried out bymove all components that become subsystems in a quality education. One of the most decisive subsystems in upgrading The quality of education is a factor of educators, namely teachers. The teacher is the end spearhead of education, because teachers directly influence, foster, and develop students' abilities to become intelligent, skilled human beings and moral. Teachers must have the basic skills needed to educators and teachers.

One of the disciplines of science that plays an important role in life and its presence is closely related to the world of education is math. Mathematics as the queen of science has meaning that mathematics is the source of other branches of science. There are so many branches of science whose theories are developed based on the development of mathematical concepts.

Mathematics is one of the basic sciences, which does not need to be doubted is another pillar of the development of science and technology. Math beside can develop independently, also develop according to the demands of the needs of other. Therefore, mastery of mathematics material for all students is necessary improved for future survival and in need daily. Mathematics subjects need to be given to all students at every level of education to equip students with the ability to think logically, analytically, systematically, critically and creatively as well as the ability to work together. In addition, mathematics subjects aim to make students appreciate the usefulness of mathematics in life, namely having curiosity, attention, and interest in learning mathematics, as well as being resilient and confident in problem solving [7].

:Learning mathematics [8] is given in all level of education, both at the junior secondary level and senior secondary education. Thus, it can be concluded that mathematics is one of the fields of study that students learn while in high school first (junior high). Mathematics education in junior high school will be the basis for studying mathematics in high school and even to the next level. Therefore, students' mastery of mathematics needs to be improved because mathematics is a very important science in various educational sciences.

One of the characteristics of mathematics is a deductive mindset [8]. Deductive reasoning can be said as general thinking that then applied or directed to something specific. Therefore, in learning mathematics, it is not only required to master only mathematical concepts but students are also expected to be able to apply concepts in everyday problem solving. This is in accordance with the opinion [9] that "mathematics is a tool to develop" way of thinking because mathematics is needed in everyday life. Furthermore According to Herman Hudoyo, problem solving is the ability that students must have in learning mathematics [9]. Based on the opinion of Herman Hudoyo, it can be concluded that in solving mathematical problems what is needed is not only results, but also the process of strategies carried out by students in solving problems the problem. Therefore problem solving is ability that students must have in solving mathematical problems.

Uno explains that mathematics is a field of science which is a tool of thought to communicate, a tool to solve various problems practical problems whose elements are logic and intuition, analysis, and construction, generality and individuality, and has branches, among others: arithmetic, algebra, geometry, and analysis [10]. Meanwhile, James explains that mathematics is the science of logic, regarding shape, arrangement, magnitude, and related concepts one another [11]. Furthermore, Ismail 
explains that mathematics is a science that deals with numbers and calculations, discuss numerical problems, regarding quantities and quantities, study the relationship of patterns, forms and structures, means of thinking, collections systems, structures and tools [12]. Based on some of these explanations, it can be concluded that mathematics is a science that deals with with numbers, calculations, shapes, and patterns obtained by uses logic or reasoning and is used to solve problems.

Learning mathematic is also not only required to master the concept of mathematics, but to be able to apply the concept of mathematics in life [13]. In mathematics, there are several materials that train students in calculations as well as sharpen their ability to analyze problems, one of which is statistics. Through statistics, students are trained to be able to view and analyze data sets so that the data sets become meaningful and can be used as needed. But in reality, there are still many students who do not really master statistics. Based on observations and giving tests conducted by researchers, information was obtained that student learning achievement was still unsatisfactory in statistics. At SMA Negeri 5 Soppeng, especially in class XII MIPA 1, the achievement of learning mathematics in statistics is still very low. This is indicated by the average score on the test given with statistics for class XII science majors is only 44.23 with the minimum completeness criteria/Kriteria Ketuntasan Minimal (KKM) 75. This means that the average score of mathematics learning achievement is still far below the KKM.

Hafid, Kartono, \& Suhito revealed the data that shows the students' difficulties in learning mathematics [14]. It is indicated by the low score of the students. The students' difficulties in learning mathematics can be seen from these following signs: (1) showing the low achievement of learning, (2) the result that has been achieved is not balance with the effort that has been done, (3) showing a slow progress in doing the tasks, (4) showing inappropriate attitude, and (5) showing the unpopular behavior [15]. According to [16], on their study also reported that in doing the circle exercise, the ninth grade students of SMP Negeri 47 Bandung having difficulties in solving a mathematical problem. Majority students have understood the main problem given by the teachers and they have found the concept that must be used in solving the problems. Otherwise, the students still doing mistakes especially on the steps of solving the problem and calculating process.

In the implementation of education, teachers play a very important role important, where teachers are responsible for disseminating new ideas to students through the teaching and learning process in the classroom. Remember the use of mathematics is required in all fields, so teaching mathematics in students must be really optimized both in quality and the quantity. In the teaching and learning process, the teacher must have the ability to and broad insight and skill in explaining the material and must also be able to arouse students' motivation or passion for learning so that students do not experience learning errors. By looking at student learning outcomes, you can the extent to which the material is mastered, so that the teacher can provide better guidance in an effort to improve the quality of education for the achievement of effective and efficient teaching objectives.

To meet the teaching objectives, the main abilities that must be Every student has the ability to read, write and count. The achievement of the goals of mathematics education and learning can be judged wrong One of them is the success of students in understanding mathematics and utilizing this understanding to solve problems in mathematics and in mathematics other sciences as measured by student learning outcomes tests.

Many elements that together can affect success in learning mathematics. Among the elements that affect, among others; students, educators/teachers, learning methods, environment. Judging from the students themselves, the factors that affect learning achievement can be grouped into two groups, namely external factors and external factors internals. External factors or factors that come 
from outside the students include: teacher factors, curriculum, facilities, infrastructure, social environment. Internal factors are factors that come from within students include interests, talents, abilities verbal skills, non-verbal skills, computing skills, visual skills room.

The low ability in the internal factors above causes low achievement in learning mathematics which is indicated by, among other things, students' inability to solve math problems and can seen from the problem solving errors. This error is known to the teacher in the teaching and learning process in the classroom as well as from the results of student work in test. This is in line with research conducted by Karnasih which stated that by knowing the difficulties experienced by students in solving mathematical story problems in the learning process can help teacher to determine where the misunderstanding occurred [17].

There is a problem solving by students in math problems need attention. Errors made by students in solving problems need to be identified according to research conducted by Ardiyanti states that students' mistakes need to be known in solving problems mathematics story in terms of four aspects, namely, understanding the problem, making mathematical models, perform computations and the ability to draw conclusions. Information about errors in solving math problems can be used to improve the quality of mathematics teaching and learning activities [18]. Finally, it is expected to improve mathematics learning outcomes.

One way that can be used to determine the cause of the low value of student learning outcomes is by analyzing the learning outcome errors in order to find out what errors often arise. By analyzing the learning outcomes errors, the teacher is expected to be able to find the causes of errors and the types of errors of students in solving math problems, especially related to statistics. Information about students' mistakes in doing math problems can help teachers in improving the quality of their learning by emphasizing things that are not good enough for students and hopefully avoiding the same mistakes. There are several methods commonly used in analyzing errors, one of which is the Newman Procedure. The Newman procedure makes it easy to analyze errors because it has five stages that students go through when solving problems. The five stages are (1) reading, (2) comprehension, (3) transformation, (4) process skills, and (5) encoding [19]. The Newman error analysis method was first introduced in 1977 by Anne Newman, a mathematics teacher in Australia. Based on what Newman argues, when students try to answer a problem in the form of a story question, the student has passed a series of obstacles in the form of stages in problem solving, which include: a) Reading, when a person reads a question, the reader will be represented according to his understanding of what he reads, or it is known as a result of the representation of the reader's mental abilities. Furthermore, students' reading ability in facing problems affects how these students will solve problems; b) Comprehension, at this stage it is said to be able to understand the problem, if students understand the meaning of all the words used in the question so that students are able to state the question in their own sentences. At this stage students must be able to show problem ideas, where problem ideas in mathematics are represented in elements of known, asked and prerequisites. Furthermore, to check the ability to understand the problem, students are asked to mention what is known and asked in the problem; c) Transformation, this stage, students try to find a relationship between the facts (which are known) and what is being asked. Furthermore, to check the ability to transform the problem, namely changing the form of the question into its mathematical form, students are asked to determine what methods, procedures or strategies will be used in solving the questions; d) Process Skill, at this stage, students are asked to implement the design problem solving plan through the problem transformation stage to produce a desired solution. At this stage, namely to check processing skills or procedures, students are asked to solve problems according to the mathematical rules that have been 
planned at the stage of transforming the problem; e) Encoding, at this stage, students are said to have reached the stage of writing answers if students can write down the answers being asked correctly [20]. Furthermore, to check the ability to write answers, students are asked to check the answers again and students are asked to interpret the final answers. Revealing the mistakes made by students means that an effort has been made to find a way out to improve student achievement. This is what encourages the author to research and discuss these conditions in this study with the title: "Analysis of Students' Errors in Solving Statistics Problems Class XII IPA SMA Negeri 5 Soppeng".

\section{METHODS}

This research uses descriptive qualitative case study methods, namely research that provides an overview of factual and systematic stimulation and events regarding factors, characteristics, and relationships between phenomena that are owned to carry out the basics only [21]. The qualitative approach is a research procedure. which produces descriptive data in the form of written or spoken words from people and observable behavior.

This type of research is descriptive qualitative research. Descriptive qualitative research is used to obtain data directly from data sources through tests and interviews. This research is described to collect information about error analysis according to Newman's procedure in solving questions on the statistics of class XII MIPA 1 students of SMA Negeri 5 Soppeng. Descriptive qualitative research can answer a question that is formulated in the formulation of the problem through the collection of data collected.

The subjects in this study were 31 students of class XII MIPA 1 SMA Negeri 5 Soppeng taken by purposive sampling. The types of student error were classified according to the Newman procedure. Data collection research using statistics test questions, which are used to locate the fault of students in solving problems.

\section{RESULTS AND DISCUSSION}

The following will show the location of the mistakes made by students in complete evaluation of statistics.

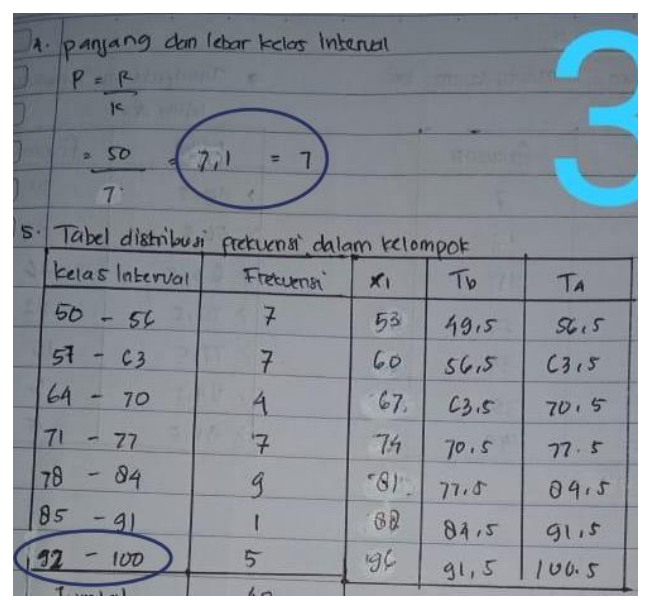

Figure 1. Example of Student Answers to Question Number 2 


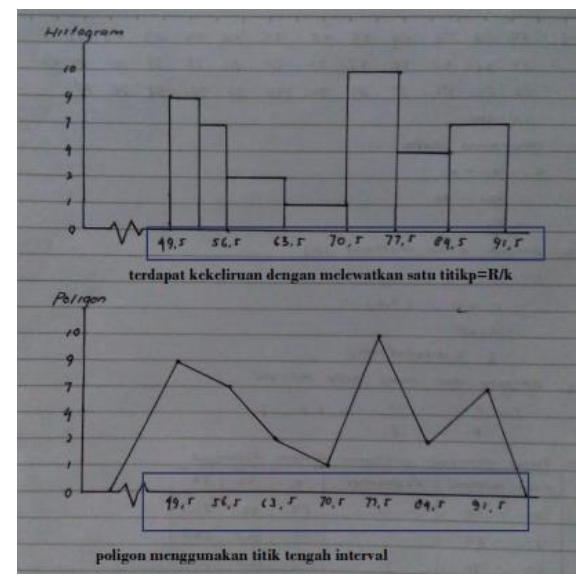

Figure 2. Example of Student Answers to Question Number 2

Tabel distribusi Frekuensi dalum kelompok
\begin{tabular}{|c|c|c|c|c|}
\hline kelas Interval & frekuensi & $\times 1$ & Th & TA \\
\hline $50-56$ & 7 & 53 & 49,5 & 56,5 \\
$57-63$ & 2 & 60 & 56,5 & $c 3,5$ \\
$64-70$ & 4 & 67 & 63,5 & 70,5 \\
$71-77$ & 9 & 74 & 70,5 & 77,5 \\
$78-84$ & 7 & 81 & 77,5 & 09,5 \\
$85-91$ & 2 & 88 & 84,5 & 91,5 \\
$92-100$ & 5 & 196 & 91,5 & 100,5 \\
\hline 2 umlah & 42 & & & \\
\hline
\end{tabular}

Figure 3. Example of Student Answers to Question Number 2

From the data analysis that had been done, it was found that some students experienced errors in processing skills and errors in writing answers. In Figure 1, the student has put the formula correctly but the rounding is wrong, in this case, the student is rounding down so that the last interval class made is not consistent with the previous interval class. In Figure 2 students experience an error in writing answers. The student was correct in the process but there were errors in the graphic depiction where the student missed a point on the histogram and the horizontal axis error on the polygon where it should have used the midpoint but the student used the class edge. In Figure 3, students have errors in writing answers, the amount of data given to students is 40 but students make miscalculations until the data that has been made into tables becomes 42.So it can be concluded that many students experience encoding errors on the questions number 2

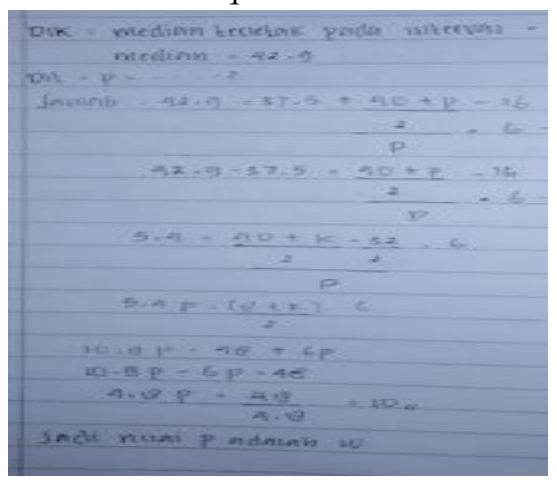

Figure 4. Example of Student Answers to Question Number 3 


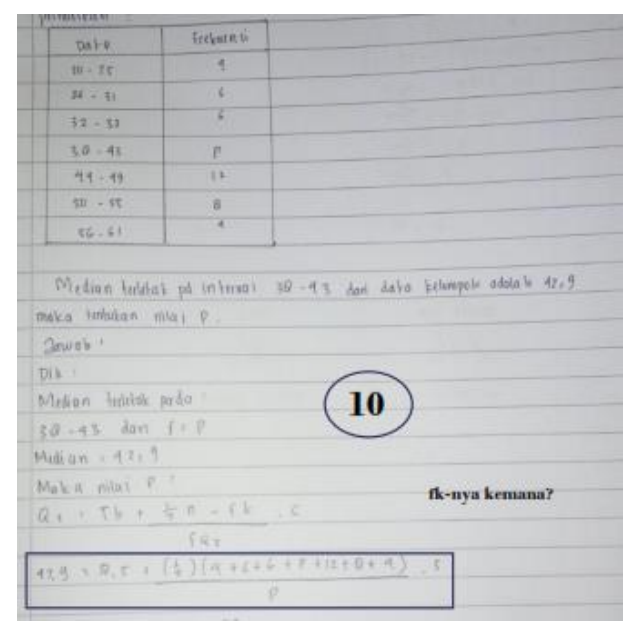

Figure 5. Examples of Student Answers to Questions Number 3

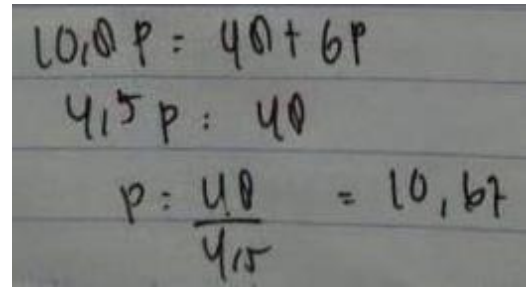

Picture 6. Examples of student answers to questions number 3

From the data analysis that has been carried out, information was obtained that some students experienced transformation errors, processing skills errors and errors in writing answers. Errors in writing answers to question number 3 arise as a result of errors in processing skills. In Figure 4, the student made several forms of errors, the student did not write down the formula to be used and immediately used numbers, the variable notation was changing, and the writing process was confusing for the assessor but the answer that was presented was correct. In Figure 5, the student's error lies in not writing one part of the formula, in this case the cumulative frequency so that the answer he writes is wrong. Whereas in Figure 6 the error lies in a slightly wrong calculation. It should be $10.8-6=4.8$ but students write down the answer as 4.5.

Based on the results of the interview, the cause of the transformation error was because students were not used to writing what was known and asked and the procedure or formula to be used even though they already understood the flow of the solution. For process skills errors and errors in writing answers are caused by students not being used to working on statistical questions in their spare time so that they are wrong in writing the completion flow. Some students argue that mistakes occur because they are working in a hurry so that they are not careful in doing it.

Another cause of the low average score of student learning outcomes because some students only do 1 or 2 of the 3 questions this is due to the lack of understanding of students on statistics material. This is because students are not familiar with online learning systems and want face-to-face learning so that some students have difficulty understanding the statistical material taught by the researcher. This reasoning is in line with the statement "it is best if mathematics learning is not done 100 percent online". Lack of understanding of students coupled with inadequate internet access, some students admitted that their answers were cheats from friends. This is similar with [22] that students are said can reach the understanding level when they can explain the problem in the question and they seem difficult to articulate the reason in understanding a particular reading. 
The result of this study have similarities with the research of Subekti \& Sari. In their study, many students make mistakes in resolving questions that ask students to write their ideas or opinions on a statement or question. Many students have not been meticulous in doing calculations, some students still can not use the existing formula to solve the problem. Student mistakes include errors in reading the intent of the question, procedural errors, and careless errors [23].

The research of [25] also examines students' errors. From the research, they got that every subject different category of error has a different ability of problem-solving. Subject with reading error type is less capable to solve the problem because they only able to do the problem-solving plan. The subjects with comprehension error type are less capable in solving a problem as they were only able to do the indicator of a problem-solving plan and do the problem-solving plan. Subjects with the transformation and process skill error can understand the problem and plan, but unable to solve the problem as they only do the understanding problem indicator and problem-solving plan. Meanwhile encoding error type able to solve the problem well as they were able to do the understanding problem indicator and problem-solving plan, and do the problem-solving plan well.

Suwarsono stated that the factors that cause student errors are cognitive factors and noncognitive factors [24]. Cognitive factors are factors related to students' intellectual abilities and students' ways of respond or digest in his mind mathematical materials such as questions, arguments, and so on. Non-cognitive factors are factors contained in students and factors that are located from outside the student's self in exploring the background students have learning difficulties so that students do error.

The causes of errors based on the Newman procedure in terms of cognitive style are not being able to understand the questions well, lack of mastery of the material, still confused about the steps to work on the questions, running out of time to solve the problems, not being thorough in working on the questions, rushing in doing the questions, not being able to solve the problems. had time to write conclusions, not used to writing conclusions [25]. This is in line with Hartini's research that the factors that cause student errors in solving story problems include: the desire of students to write short answers, students' ignorance that the sentences/mathematical models that he wrote are wrong, student confusion, lack of thoroughness of students in doing calculations, and students are less accustomed to writing conclusions [26]. This is in accordance with the results of research by Nurussafa'at, the factors that cause student errors in working on story questions are haste, lack of thoroughness, do not understand the question, incompletely write known and asked, do not understand the material, forget the formula used, less processing time [26].

Rahmawati \& Permata suggested for students who made mistakes in solving linear program story problems, students should study linear programming material well in order to have ability to change the problem into a mathematical model, students should also a lot of practice working on story problems with easy completion steps complete. For teachers, it is better in the learning process to train students to solve story problems with complete and structured completion steps, namely by writing down what is known and what is asked, choosing correct arithmetic procedures and operations, and write the final answer as conclusions so that errors made by students can be minimized. Teacher should provide more practice with story questions that vary from simple to more complex questions [27].

This study focuses on examining students' errors in solving statistical problems. So that, other researchers who are interested can examine misunderstanding of concepts or misconceptions of students about one of the materials in mathematics on statistics material. In addition, other researchers can developing research on student error analysis in solving problems based on Newman's 
procedures on other mathematical material, adding to the subject research in order to obtain the types of errors and the factors that cause errors more detailed and in-depth, conducting research in an effort to find alternative strategies to minimize errors made by students.

\section{CONCLUSIONS AND SUGGESTIONS}

Based on the results of the analysis and discussion above, it can be concluded that the mistakes made by students of class XII MIPA 1 SMA Negeri 5 Soppeng were making mistakes in reading errors, comprehension errors, process skills errors, and encoding errors. The cause of the error is a lack of knowledge on statistical material, constrained by networks to find references, students are not familiar with the online learning system, rarely practice working on problem solving problems, and are not careful in calculating and writing answers. Solutions that can be used to minimize these errors are students reading questions more than once so that no information is missed, learning to understand concepts, practicing diligently, answering problem solving questions, and checking the results of calculations and answers obtained. Based on the results of the research that has been carried out, the researcher through this paper provides suggestions to the teacher, to always make improvements in the learning process as an effort. In addition, teachers are expected to be able to make learning that can be adjusted to the current pandemic conditions to minimize errors in solving statistical problems, one of which is to emphasize more concepts to students and guide and motivate students to practice answering statistical problem solving questions. For students, they should communicate the difficulties experienced in the learning process to teachers and friends who are more familiar with the material.

This study focuses on examining students' errors in solving statistical problems. Other researchers who are interested can examine misunderstanding of concepts or misconceptions of students about one of the materials in mathematics on statistics material. Other researchers also can developing research on student error analysis in solving problems based on Newman's procedures on other mathematical material, adding to the subject research in order to obtain the types of errors and the factors that cause errors more detailed and in-depth, conducting research in an effort to find alternative strategies to minimize errors made by students.

\section{REFERENCE}

[1] A. Apriliawan, S. Gembong, and S. Sanusi, "Analisis Kesalahan Penyelesaian Soal Uraian Matematika Siswa MTs Pada Pokok Bahasan Unsur-Unsur Lingkaran," JIPM (Jurnal Ilm. Pendidik. Mat., vol. 1, no. 2, pp. 1-8, 2013.

[2] Saihu and B. Rohman, "Pembentukan Karakter Melalui Model Pendidikan Transformatife Learning Pada Santri Di Pondok Pesantren Nurul Ikhlas Bali," J. Pendidik. Islam, vol. 8, no. 2, pp. 435-452, 2019.

[3] W. B. Sulfemi and H. Minati, "Meningkatkan Hasil Belajar Peserta Didik Kelas 3 SD Menggunakan Model Picture and Picture dan Media Gambar Seri," J. Pendidik. Sekol. Dasar, vol. 4, no. 2, p. 228, 2018.

[4] M. Samin, Telaah Kurikulum Pendidikan Menengah Umum/Sederajat. Medan: Perdana Publishing, 2016.

[5] N. Purwanto, Pengantar Pendidikan. Yogyakarta: Graha Ilmu, 2014.

[6] Mardianto, Psikologi Pendidikan. Medan: Perdana Publishing, 2012.

[7] A. Kistian and V. Verawati, "The Effect of Problem Based Learning (PBL) Learning Models on Mathematic Problem Solving Ability Students in Primary School," Budapest Int. Res. Critics 
Inst. Humanit. Soc. Sci., vol. 3, no. 3, pp. 2325-2334, 2020.

[8] N. Farida, "Analisis Kesalahan Siswa SMP Kelas VIII Dalam Menyelesaikan Masalah Soal Cerita Matematika," AKSIOMA J. Progr. Stud. Pendidik. Mat., vol. 4, no. 2, pp. 42-52, 2015.

[9] P. Rahayuningsih and A. Qohar, "Analisis Kesalahan Menyelesaikan Soal Cerita Sistem Persamaan Linear Dua Variabel (SPLDV) dan Scaffolding-nya Berdasarkan Anaslisis Kesalahan Newman pada Siswa Kelas VIII SMP Negeri 2 Malang," J. Pendidik. Mat. dan Sains, vol. 2, no. 2, pp. 109-116, 2014.

[10] H. B. Uno, Model pembelajaran: menciptakan proses belajar mengajar yang kreatif dan efektif. Jakarta: Bumi Aksara, 2014.

[11] E. Suherman, Strategi Pembelajaran Matematika Kontemporer. Bandung: PT Remaja Rosdakarya, 2011.

[12] M. A. Hamzah and Muhlisrarini, Perencanaan dan Strategi Pembelajaran Matematika. Jakarta: Raja Grafindo Persada, 2014.

[13] D. Oktaviana, "Analisis Tipe Kesalahan Berdasarkan Teori Newman Dalam Menyelesaikan Soal Cerita Pada Mata Kuliah Matematika Diskrit," Edu Sains J. Pendidik. Sains Mat., vol. 5, no. 2, p. 22, 2018.

[14] H. Hafid, Kartono, and Suhito, "Remedial Teachinguntuk Mengatasi Kesulitan Belajar Siswa pada Kemampuan Pemecahan Masalah Matematika Berdasarkan Prosedur Newman," Unnes J. Math. Educ., vol. 5, no. 3, pp. 257-265, 2016.

[15] S. B. Djamarah, Psikologi Belajar. Jakarta: Rineka Cipta, 2011.

[16] D. Ruswati, W. T. Utami, and E. Senjayawati, "Analisis Kesalahan Siswa SMP dalam Menyelesaikan Soal Kemampuan Pemecahan Masalalah Matematis Ditinjau dari Tiga Aspek," MAJU J. Ilm. Pendidik. Mat., vol. 5, no. 1, pp. 91-107, 2018.

[17] I. Karnasih, "Analisis Kesalahan Newman pada Soal Cerita Matematika (Newman's Error Analysis in Mathematical Word Problems)," Parad. J. Pendidik. Mat., vol. 8, no. 1, pp. 37-51, 2015.

[18] Ardiyanti, H. Bharata, and T. Yunarti, "Analisis Kesalahan Siswa Dalam Menyelesaikan Soal Cerita Matematika," J. Pendidik. Mat. Univ. Lampung, vol. 2, no. 7, pp. 1-9, 2014.

[19] P. Singh, A. A. Rahman, and T. S. Hoon, "The Newman procedure for analyzing Primary Four pupils errors on written mathematical tasks: A Malaysian perspective," in Procedia - Social and Behavioral Sciences, 2010, vol. 8, pp. 264-271.

[20] T. Solfitri, Kartini, H. M. Siregar, and R. Syari, "The Analysis of Students' Errors in Using Integration Techniques," in Proceeding of the SS9 \& 3rd URICES, 2019, Pekanbaru, Indonesia, 2019, pp. 328-335.

[21] M. Rahardjo, Studi Kasus Dalam Penelitian Kualitatif: Konsep dan Prosedurnya. Malang: UNIVERSITAS ISLAM NEGERI MAULANA MALIK IBRAHIM MALANG PROGRAM PASCASARJANA, 2017.

[22] D. D. Pratiwi, "Analisis Kemampuan Komunikasi Matematis dalam Memecahkan Masalah Matematik a Sesuai dengan Gaya Kognitif dan Gender," Al-Jabar J. Pendidik. Mat., vol. 6, no. 2, pp. 131-141, 2015.

[23] F. Eko Subekti and D. Puspita Sari, "Errors in solving math problems based on newman type," in Journal of Physics: Conference Series, 2021, vol. 1778, no. 1, pp. 1-8.

[24] S. Suwarsono, Penggunaan Metode Analisa Faktor Sebagai Suatu Pendekatan Untuk Memahami SebabSebab Kognitif Kesulitan Belajar Anak Dalam Matematika. Yogyakarta: IKIP Sanata Dharma, 1982.

[25] S. R. Amalia, "Analisis Kesalahan Berdasarkan Prosedur Newman Dalam Menyelesaikan Soal Cerita Ditinjau Dari Gaya Kognitif Mahasiswa," AKSIOMA, vol. 8, no. 1, pp. 17-30, 2017.

[26] F. A. Nurussafa'at, I. Sujadi, and Riyadi, "Analisis Kesalahan Siswa Dalam Menyelesaikan Soal Cerita Pada Materi Volume Prisma Dengan (Fong's Shcematic Model for Error Analysis Ditinjau Dari Gaya Kognitif Siswa (Studi Kasus Siswa Kelas VIII Semester II SMP IT Ibnu 
Abbas Klaten Tahun Ajaran 2013/201," J. Elektron. Pembelajaran Mat., vol. 4, no. 2, pp. 174 187, 2016.

[27] D. Rahmawati and L. D. Permata, "Analisis Kesalahan Siswa Dalam Menyelesaikan Soal Cerita Program Linear Dengan Prosedur Newman,” J. Elektron. Pembelajaran Mat., vol. 5, no. 2, pp. 173-185, 2018.

\section{BIOGRAPHY}

\section{Winaldi}

He was born of Soppeng on November 6, 1998. Now a student in the Tadris Matematika S1 program at the Institut Agama Islam Negeri ParePare. Phone number 081257140499 and email: winaldi@iainpare.ac.id

Gusniwati

Lecturer in the Institut Agama Islam Negeri ParePare. He obtained his Strata-2 (S2) in Universitas Tadulako. Email: gusniwati@iainpare.ac.id

Andi Aras

Lecturer in the Institut Agama Islam Negeri ParePare. He obtained his Strata-2 (S2) in Universitas Negeri Makassar. Email: aras9math@gmail.com 